\title{
Agency costs and credit availability: an international study
}

\author{
Mejda Bahlous-Boldi \\ Finance, RIT, Dubai, United Arab Emirates and \\ IHEC, Carthage, Tunisia
}

\begin{abstract}
Purpose - This paper aims to investigate the link between agency costs mitigation via three levels of rights protection (minority rights protection, enforcing contracts, resolving insolvency issues) provides the propitious climate for financing investment opportunities around the world.

Design/methodology/approach - We use Bartlett's three-group method to stratify countries based on how well they protect investors as measured by the scores provided in the Doing Business dataset developed by the world bank for 189 countries. We then test a variety of independent hypotheses that the alleviation of agency costs via three levels of protection (minority investors' rights, contract enforcement, resolving insolvency issues) is associated with better access to credit via the banking system, better valuation of listed firms via the stock market and higher investment and growth.

Findings - Our findings support Agency Theory which explains why the absence of legal protection of external investors leads to stock markets and financial institutions failing to fulfill their role of financing the economy.

Practical implications - The policy implication from this study indicates that countries ought to (1) develop legislation that protects investors' rights, (2) improve the quality of their judicial system in terms of enforcing the legislation and (3) build the framework for resolving disputes during insolvency as these are important ingredients for a developed financial system.

Originality/value - We use the World bank dataset and a new methodology to quantify the significance of the relationship between minority rights protection, ineffective enforcement, lack of bankruptcy laws and access to firm financing via the banking sector and the stock market. It provides new evidence that the quality of the judicial system in a country matter for firms' ability to raise financing and enhance value creation.
\end{abstract}

Keywords Agency Theory, Shareholders'rights protection, Enforcing Contracts, Bankruptcy Law, Minority Investors, Banking Sector development, Stock Market development

Paper type Research paper

\section{Introduction}

In the absence of strong standards of disclosure, surveillance and enforcement, the high agency costs related to the lack of transparency lead to losses for corporations and inhibit value creation. In the absence of collateral registry and of bankruptcy law, banks will be reluctant to lend to entrepreneurs with daring ideas, and investors will be reluctant to take any ownership interest in companies in need to raise capital to finance their growth. In this case, financial markets cannot play a major role in mobilizing savings and in providing funding to innovative projects.

This paper provides new evidence that poor minority rights protection, ineffective enforcement, and lack of bankruptcy laws is associated with limited access to the banking sector, lower firm valuation, and financing of investment opportunities via the stock market. Central to this issue, agency theory and asymmetry of information explain why in the

(C) Mejda Bahlous-Boldi. Published in European Journal of Management and Business Economics. Published by Emerald Publishing Limited. This article is published under the Creative Commons Attribution (CC BY 4.0) licence. Anyone may reproduce, distribute, translate and create derivative works of this article (for both commercial and non-commercial purposes), subject to full attribution to the original publication and authors. The full terms of this licence may be seen at http://creativecommons. org/licences/by/4.0/legalcode

The author would like to thank external reviewers for their helpful comments.

Received 26 June 2020 Revised 22 February 2021 13 April 2021

Accepted 17 April 2021

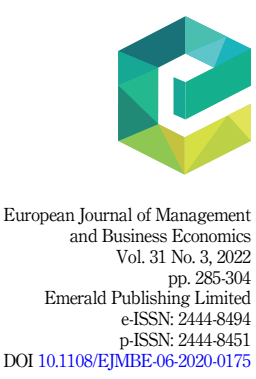


EJMBE 31,3 absence of legal protection of outside investors, stock markets fail to fulfill their role of financing the economy. For instance, if capital providers are not protected from expropriation by controlling shareholders or by opportunistic managers as a result of the majority rule or centralized control, the temptation to take on perquisites and other private benefits will result in losses for the corporation and more for noncontrolling shareholders.

We use the Doing Business database developed by the World Bank to investigate the relationship between the legal business environment and firm financing via the banking channel and the stock market channel, as well as firm investment in 189 countries during 2003-2017. The indices are used to measure the extent of shareholder's protection, enforcing contracts, and resolving insolvency, as well as some indicators of availability of credit to the private sector, valuation of corporations and stock market liquidity in addition to Economic indicators. Our test concludes that in countries that protect better investors, lenders, and minority shareholders, more credit is available for corporations via the banking sector and stock market is more liquid and efficient.

This paper is organized as follows: Section 2 provides a literature review on agency costs and firm financing and the previous research linking the legal environment to a firm's access to financing. Section 3 presents our test of the relationship between access to financing and three aspects of creditor's rights protection: we focus on minority rights, quality of the judicial system and legislation that resolves insolvency issues. Section 4 concludes.

\section{Agency costs and firm financing: literature review}

When investment opportunities exist, underinvestment occurs, mainly because corporations are unable to obtain the amount and maturity of financing needed. Entrepreneurs cannot raise equity finance mainly because of microeconomic factors like asymmetric information and conflicts of interest between lenders and borrowers and macroeconomic factors like credit control policies and the legal and institutional environment in which corporations and financial institutions operate. In a situation where managers are more likely to have opportunistic behavior and engage in negligent behavior without prosecution, outside investors will be reluctant to provide the capital needed. In a situation where ownership is concentrated between the hands of few main shareholders, new investors will hesitate to take a minority position if there is a risk of expropriation. In a situation where financial intermediaries are unable to manage risk efficiently or to collect reliable information and monitor the use of funds by borrowers, lenders will be reluctant to provide long-term funds to those entrepreneurs whose risk is difficult to assess. (See (Ross (1973) for a comprehensive model of the theory of Agency).

Capital market imperfections like credit control and asymmetric information, as well as poor rights protection for capital providers, therefore, become sources of financing constraints that can lead to suboptimal level of investment and thereby hampers economic growth.

Perhaps the starting point of the extensive research linking the extent of the legal protection of outside investors to firm financing can be found in the seminal work by Nobel prize winners Jensen and Meckling (1976) in the theory of the Firm. According to them, agency costs include all costs frequently referred to as contracting costs, transactions costs, moral-hazard costs, and information costs. In their model, agency theory explains why maximizing the value of the firm is not necessarily optimal for all stakeholders. Jensen and Meckling explain in their conclusion that "The growth in the use of the corporate form as well as the growth in market value of established corporations suggests that at least, up to the present, creditors and investors have by and large not been disappointed with the results, despite the agency costs."

Nevertheless, the failure of the cooperative form of society to accumulate and create wealth, which led to the end of the cold war in 1990, is precisely due to the general problem of 
agency costs in the form of shirking, monitoring costs and losses incurred because of ineffective or inexistent incentives to work for the common good.

\subsection{Agency conflicts}

Three main conflicts arise from the separation of ownership, creditors and control. (1) Agency conflicts between shareholders and managers; (2) agency conflicts between minority shareholders and majority shareholders that could result in the expropriation of minorities by the ruling shareholders; and (3) agency conflicts between shareholders and creditors due either to moral hazard or due to the selfish behavior of shareholders in a likely situation of bankruptcy.

2.1.1 Agency costs resulting from conflict of interest between hired managers and shareholders. In this category, agency costs can be of three origins: first, losses incurred from the opportunistic behavior of managers who pursue their own goals at the expense of the shareholders will reduce the value of the firm. Second, limited access to information about how their wealth is managed creates risk for the shareholders and potential for being abused by the managers. Third, moral hazard, i.e. the tendency for the managers to undertake risky actions and to be less careful knowing that the potential burdens of such risks, if things go bad, will be borne by the shareholders adds to the business risk. Gormley and Matsa (2016) explain that the opportunistic behavior from the managers manifests itself not only in two value-destroying activities such as creating private benefits or exerting less effort than shareholders desire (shirking) but also in a third action motivated by risk aversion or career concerns. As a matter of fact, managers have the incentive to take on less risk than is desired that reduces the firm's risk, or in other words, "playing it safe" when it is not optimal to do so. This, often-ignored form of agency costs, is costly for the firm and for the economy as a whole as elucidated by the authors "by preventing individual firms from taking risk, risk related agency conflicts could hamper aggregate investment and economic growth" (Gormley and Matsa (2016) p. 432).

2.1.2 Agency costs resulting from the conflict of interest between minority shareholders and majority shareholders. In case the ownership is concentrated, a conflict of interest is likely to exist between controlling shareholders who possess the majority of interest and commensurate voting rights and the minority noncontrolling shareholders. The oppressive actions of controlling shareholders include but are not limited to withholding dividends, asset sale, mergers, compensation and perks to majority shareholders that are employees, and other self-interested discriminatory actions (Farrar and Boulle, 2001). La Porta et al. (1998) claim that in countries "with poor legal protection of outside investors, ownership concentration is a substitute for legal protection" because investors are not willing to take minority positions as they are more likely to be expropriated. Burkart and Panunzi (2006) argue that legal protection, same as monitoring, weakens managerial incentives to divert shareholders' wealth. Their model shows that legal protection can either complement or replace ownership concentration. Here again, legislation is needed to ensure that minority rights are protected. Without it, the company cannot raise equity capital easily.

2.1.3 Agency costs resulting from the conflict between shareholders and creditors. In this case, the creditors are principals, while the company, its shareholders, and managers, are agents. The losses for the creditors result from three situations: first, the absence of good and effective legislation that protects creditors from being expropriated due to moral hazard arising from the fact that the fund provider has no control over the use of funds lent and the degree of risk taken by the fund managers, creditors will be reluctant to provide the funds needed. Second, absent collateral registry, lenders cannot rely on companies' assets to be used as collateral for a bank loan. Third, in a situation of bankruptcy, the creditors are the owners
Agency costs and credit availability 
EJMBE 31,3

of the assets that are still managed by managers who were hired to pursue the goal of maximizing shareholder's wealth. Managers in this situation will act in the interest of the shareholders and not the creditors who are owners of the distressed firm current assets. In this case, the creditors need protection from the abusive behavior of the managers and the shareholders. The 2008 financial crisis, as well as the 2020 current health crisis, have brought into the spotlight the need for bankruptcy law as many firms were forced into financial distress or bankruptcy. If financially distressed firms can be saved from liquidation, efficient bankruptcy laws will encourage reorganization and protect creditors from further losses. On the other hand, firms that cannot benefit from reorganization should be liquidated and money returned to creditors. Gine and Love (2010) explain that an effective Bankruptcy regulation should seek to minimize reorganization costs, ensure that viable firms are reorganized and unviable firms are liquidated, support speedy recovery of reorganized firms and therefore benefit financial and economic development. Good bankruptcy law that constrains managers to limit the potential for abuse of creditors' interest is a requirement for raising money via debt financing.

\subsection{How can agency costs be reduced?}

Two types of strategies are generally put forward that intend to act as a deterrent from taking these harmful actions for the principal: contractual governance strategies and regulatory strategies and their enforcement (Armour et al., 2009).

(1) Contractual strategies include a code of conduct that constrains the managers to act honestly and in good faith and reward and incentive strategies that could induce managers to comply with the rules and act in the best interest of the shareholders. Many of these strategies are, however, not found to be always effective and are paradoxically benefiting more the sinful agent than the principal victim as they lead to excessive management compensation or generous packages like golden parachutes benefiting the incompetent managers in case of a takeover.

(2) Regulation in the form of corporate and securities laws aiming to reduce asymmetry of information imposes responsibilities on managers. For instance, the disclosure requirement imposing regular release of quality information about the company's performance, audited financial statements, the requirement of shareholders' approval for major decisions, holding annual shareholders' meetings, etc.

(3) In addition to corporate law, bankruptcy law is also needed to protect both shareholders and creditors when the business is experiencing financial distress or liquidation. An efficient bankruptcy proceeding saves costs to the business, the stakeholders and the economy by encouraging reorganization for viable firms and the liquidation of unviable firms.

(4) Although laws and regulations are necessary, they are not sufficient. For instance, if breaching the law does not lead to prosecution, then the legislation will not protect outside investors. There must be enforcement mechanisms that accompany the legislation for this legislation to be effective. When regulatory practices are based on the rule of law and the court system is fast and efficient, the regulation becomes effective in protecting investors and lenders. Therefore, enforcing the rule of law is a gauge of the quality of the judicial system.

\subsection{Previous research on the investors' legal protection and firm financing}

Several empirical studies suggest a positive link between legal protection and financial market development. According to these studies, better shareholders' protection would 
lead to more efficient financial markets and to higher firm financing in the form of equity capital. For instance, La Porta et al. (1997) show that better legal protection is associated with stock markets that are more valuable and a larger number of listed firms. Kumar et al. (1999) argue that firms tend to prosper and to have larger listed firms in terms of their sales to assets in countries with better legal protection. Claessens et al. (2000) and La Porta et al. (2002) show that a higher valuation of listed firms relative to their assets is associated with a better legal environment. La Porta et al. (2000) also document greater dividend payouts in countries with better legal protection of outside investors. La Porta et al. (1998), and Claessens et al. (2002) conclude that good investors' protection is associated with less potential for shareholder expropriation as there is a lower concentration of ownership and control and lower private benefit of control (Dyck and Zingales (2004)). Zingales (1994), Nenova (1999) and Wurgler (2000) document a strong correlation between shareholders' protection and investment opportunities. Love (2003) shows that the sensitivity of investment to cash flow depends negatively on financial development, which suggests that in countries where the financial system is underdeveloped, companies can only invest if they generate enough cash flow. An underdeveloped financial system is usually characterized by poor legal shareholders' protection (Shleifer and Wolfenzon (2002). In a recent study, Burunciuc and Gonenc (2021) used a dataset from the Doing Business database developed by the World Bank to identify 65 countries that undertook reforms protecting minority shareholders and investigate the impact of these reforms on firms operating in these countries. They provide evidence of a positive and significant impact of reforms that protect minority shareholders on the firm value measured by Tobin's $Q$ and on firm's performance.

Carlin and Mayer (2003) show that the characteristics of industries that prosper in a country depend on the efficiency of the financial system in that country. Beck et al. (2005) investigated whether the financial, legal, and corruption obstacles that firms report affect their growth rates. They conclude that the legal environment is one of the factors that impact firms' growth. Armour et al. (2008) test the link between increased shareholders protection and stock market development using stock market capitalization, the value of stocks traded and the number of listed firms and concluded that there is no evidence of a long-run impact of legal change on stock market development. Berdugo and Hadad (2009) propose a model in which legal investors' protection in the high-tech industry mitigates agency problems between investors and innovators and leads to higher productivity and growth. They predict a high correlation between legal investors' protection and the size, productivity, and growth of the high-tech industry. According to this study, better investor protection facilitates the access to nonbank finance and enhances entrepreneurship. Deakin et al. (2018) use a recently constructed dataset to test the hypothesis that the strengthening of shareholder rights during the mid-1990s and 2000s in 28 developed and emerging countries promoted stock market development in those countries. They report a weak evidence that shareholder protection promoted stock market development. They found stronger evidence of a reverse relationship and conclude that at the county level, the stock market development caused a change in the legal environment which was the response to better shareholders' protection.

Safavian and Sharma (2007) used firm-level data to test the hypothesis that the effectiveness of creditor rights is strongly linked to the efficiency of contract enforcement in 27 European countries. They found a strong association between access to bank credit and creditor's rights in countries with better creditors' rights. The association is much weaker in countries with inefficient courts. Several institutions, among them the World Bank and the IMF, have advised developing countries on the importance of the "Rule of Law" to promote investment and wealth creation.

Ponticelli and Alencar (2016) show that in Brazil, a bankruptcy reform and better enforcement increasing secured creditors' protection, led to better access to finance and a
Agency costs and credit availability 
EJMBE 31,3

larger increase in investment and output. Neira (2019) provides evidence from a sample of OECD countries that an efficient bankruptcy framework is associated with a higher proportion of new bank loans allocated to large firms and better productivity of these firms.

Even in countries that are supposed to protect creditors, like the USA, through Chapter 11 of bankruptcy code, court decisions may be inefficient and not beneficial to creditors as it is supposed to be. Antill (2020) shows that the court ruling for a liquidation and asset sale instead of emergence, and reorganization, in many cases, is detrimental to creditors. The author finds that these costly liquidations lead to reduced creditor recovery by 14 cents per dollar of debt. The study also concludes that in $21 \%$ of liquidation cases, the ruling does not maximize creditors' recovery. They note that equity holders, for instance, would benefit from protecting creditors as it would lead to a lower cost of capital for the firm (Antill and Grenadier (2019)). Other recent studies suggest that suboptimal court rulings in favor of liquidation that are harmful to creditors are more likely to exist in areas with low access to credit Bernstein et al. (2019a, b).

\section{Empirical investigation of the relationship between legal protection and firm financing \\ 3.1 Data}

In this study, we aim to assess the relationship between the legal framework for protecting investors and the financial market's depth, growth and liquidity. For this purpose, we used the indices from the Doing Business Database that measure the quality of the legal system in 189 countries. From our knowledge, the Doing Business Database is the only one available that provides quantitative indicators on business regulations to measure the extent of investor rights level of protection, contract enforcement and resolving insolvency individually in a way that allows for a direct test of our hypothesis. Also, it allows for comparison between 189 economies as the same methodology of administering the survey and constructing the indicators is used across countries. However, although this survey exists since 2003, many of the indicators have only a few observations over time, making the data set an unbalanced time series. Also, some countries have started being covered by the World bank survey only in the most recent years.

To test the hypothesis that the legal environment in which businesses operate matters for the availability of credit via the banking sector, the liquidity and depth of the stock market, and for firm investment and growth, two sets of data are needed: indicators of the quality of the legal environment and indicators of firm access to credit and equity finance.

3.1.1 Investors' legal protection indicators. Outside investors need three levels of protection: (1) laws that prohibit negligent and opportunistic behavior by the agent, (2) mechanism of enforcing the regulation and (3) procedures and laws aiming to resolve insolvency issues. If improving the legal environment by ensuring the rule of law in business dealings leads to better financing of the economy and of the corporate sector, then we can conclude that a better legal environment can enhance wealth creation and reduce poverty. The "Doing Business" dataset from the World Bank provides indicators for two aggregate measures of the quality of the legal environment. More specifically, some of these indicators measure three aspects of the business environment that are of interest here: protecting minority investors, enforcing contracts, and resolving insolvency.

Protecting investors: as explained by the Doing Business report, investors' protection indicators assess the regulation in protecting investors and shareholders first from conflict of interest and second in protecting rights in corporate governance.

(1) PMI-SMIP Strength of Minority Investor Protection Index is the average of the PMI ECIR and PMI ESG. 
The Extent of conflict-of-interest regulation index PMI - ECIR (0-10) assesses the transparency, disclosure requirement, and company's director liability in cases of selfdealing and mismanagement of company's affairs available starting from 2014. This is the new version of PMI-SIP (Strength of Investor Protection Index) available from 2006 until 2014. More precisely, PMI - ECIR is the average of the following indicators:

(2) PMI-ED Extent of disclosure index measures Approval and transparency of relatedparty transactions.

(3) PMI -ESS Ease of shareholders' suit: Liability of company directors for self-dealing.

(4) PMI-EDLI Extent of Director Liability: Shareholders' ability to obtain corporate documents before and during derivative or direct shareholder litigation.

The rights in corporate governance are assessed through the PMI-ESG indicator that measures the role of shareholders in major corporate decisions, their protection from undue board control and entrenchment, and the level of transparency in matters related to executive compensation, annual meetings, and audits. The higher the values the better is the shareholder's protection.

(5) The PMI ESG (Extent of shareholder governance index 0-10) index is calculated as the average of the following indexes.

- PMI-ESR (Extent_of_shareholder_rights_index_0-10) measure rights and roles in major corporate decisions.

- PMI-EOC (Extent_of_ownership_and_control_index_0-10) measures Governance safeguards protecting shareholders from undue board control and entrenchment.

- PMI-ECT (Extent_of_corporate_transparency_index_0-10) measures Corporate transparency on significant owners, executive compensation, annual meetings and audits.

Enforcing contracts: As described by the World Bank report, the enforcing contract index measures the extent of the efficiency of the regulatory practices in enforcing the rule of law. This indicator focuses on the efficiency of the commercial court system and the quality of judicial processes in the country. It is based on the procedures, time and cost to resolve a commercial dispute between two firms through the courts (World Bank report on protecting investors).

(1) EC -TD Time in Days to resolve a commercial dispute through a local first-instance court (the lower the better).

(2) EC - C Attorney, Court and enforcement costs as \% of claim value (lower is better).

(3) EC-CE Attorney fees, court costs and enforcement cost as $\%$ of estate (lower is better).

(4) EC-P Number of procedures needed to resolve a commercial dispute by enforcing a contract. (The lower, the better).

Resolving Insolvency: The third level of protection is related to stakeholders' rights in a situation of financial distress. In countries where bankruptcy laws are inexistent or inefficient, losses to all parties, as well as to the economy in terms of jobs lost and the impact on distressed families, can have far-reaching implications. Creating a framework to help distressed firms find a way for reorganization and saving the business from bankruptcy when it is still viable or helping in liquidating nonviable firms to prevent further losses is
Agency costs and credit availability 
EJMBE 31,3 expected to have a positive impact on the ability of firms to raise funds and to invest. The resolving insolvency indicator of the World Bank measures the time, cost, outcome and recovery rate for commercial insolvency and strength of the legal framework for insolvency (World Bank report on protecting investors).

(1) RI - SI: Strength_of_insolvency_framework_index_0-16_is an aggregate measure of the quality of insolvency laws that govern relations between debtors, creditors, and the court. The higher this index, the more advantageous is the treatment of debtors.

(2) RI - RR: Recovery rate cents on the dollar is the number of cents to the dollar recovered by secured creditors through judicial reorganization, liquidation, or debt enforcement proceedings (the higher, the better). It considers the outcome, the time and the costs of proceedings during reorganization or liquidation. (World Bank Doing Business Report).

(3) RI - CE: Cost as Percent of Estate (the lower, the better).

(4) RI - CP: Creditor Participation Index_0-4.

(5) TRI- Time to resolve insolvency in years (the lower, the better).

For each one of these levels of protection, the World Bank also calculates an index based on the ranking of each country relative to the lowest protection in the group of countries (frontier). These resulting indexes are the Distance to Frontier Indexes (DTF); the higher any of these indexes, the better is the protection of rights. We used the four DTF indexes and two more indicators LGRI and DCI (Depth of credit information index $(0=$ low to $8=$ high), which measures rules affecting the scope, accessibility, and quality of credit information available through public or private credit registries (Source: World Bank, Doing Business project) and the Strength of legal rights protection LGRI Strength of legal rights index measures the degree to which collateral and bankruptcy laws protect the rights of borrowers and lenders. The index ranges from 0 to 12 , with higher scores indicating that these laws are better designed to expand access to credit:

(1) PMI_DTF Protecting Minority Investors; Distance to Frontier.

(2) EC_DTF Enforcing Contracts; Distance to Frontier.

(3) RI_DTF Resolving Insolvency; Distance to Frontier.

(4) ALL_DTF All three levels of protection: Distance to Frontier.

(5) DCI (Depth of credit information index $(0=$ low to $8=$ high).

(6) LGRI Strength of Legal rights Index ( $0=$ low to $12=$ high).

3.1.2 Firm financing indicators. To assess the ability of investors and the business sector to access to credit and financing, we have three sets of indicators related to the banking sector development, stock market development and economic activity indicators:

3.1.2.1 Credit and banking sector efficiency Indicators.

(1) Domestic Credit to the private sector as a \% of GDP (DCPS) refers to financial resources provided to the private sector by financial corporations, such as through loans, purchases of nonequity securities, and trade credits and other accounts receivable, that establish a claim for repayment. For some countries, these claims include credit to public enterprises. The financial corporations include monetary authorities and deposit money banks, as well as other financial 
corporations where data are available (including corporations that do not accept transferable deposits but do incur such liabilities as time and savings deposits). Examples of other financial corporations are finance and leasing companies, money lenders, insurance corporations, pension funds, and foreign exchange companies [1].

(2) DCB Domestic Credit to the private sector by Banks as \% of GDP (DCB) is defined as financial resources provided to the private sector by other depository corporations (deposit taking corporations except central banks), such as through loans, purchases of nonequity securities, and trade credits and other accounts receivable, that establish a claim for repayment. For some countries, these claims include credit to public enterprises.

(3) Domestic Credit provided by financial sector as\% of GDP (DCP): It includes all credit to various sectors on a gross basis, except for credit to the central government, which is net. The financial sector includes monetary authorities and deposit money banks, as well as other financial corporations where data are available (including corporations that do not accept transferable deposits but do incur such liabilities as time and savings deposits).

(4) Gross Domestic Savings as \% of GDP (GDS) is calculated as GDP less final consumption expenditure. It is intended to measure the total savings of the household sector, private corporate sector, and public sector. We expect to find a positive and significant link between GDS and the measures of the quality of the judicial system, as well as protecting investors and resolving insolvency issues.

3.1.2.2 Stock market functioning and its extent to finance the corporate sector.

(1) Market Capitalization of listed companies (Log-MC): this variable is meant to measure the total value of companies listed, our hypotheses are that in a business environment with better rights protection laws and a more efficient judicial system that enforces contracts and better functioning of bankruptcy administration, firms have a higher valuation. This indicator of the size of the stock market is calculated by the sum of the market capitalization of all listed companies in current USD (number of stocks of each company multiplied by its stock price). We use the log transformation of market capitalization to make the mean independent of the SD.

(2) Market Capitalization as \% of GDP (MC): measures the market capitalization of all listed companies as a \% of GDP. It helps assess the value of the shares traded per dollar generated in GDP. We expect this indicator to be higher in countries with better indicators of the legal environment.

(3) Stocks Traded Turnover Ratio of Domestic shares (STT): is the value of domestic shares traded divided by their market capitalization. It measures the liquidity of the stock market. A high turnover is an indication of well-functioning stock market and better valuation of corporations. Our hypothesis is that a good legal system is needed for a well-functioning stock market.

(4) Stocks Traded, total value as \% of GDP (STTV): This variable is the value of shares traded measured as the total number of shares traded, both domestic and foreign, multiplied by their respective matching prices of their end of year value divided by GDP. We expect to find a positive association between this variable and indicators of the quality of the legal environment. 
EJMBE 31,3

\section{4}

3.1.2.3 Economic activity, investment, and value creation indicators.

(1) Gross capital formation in constant 2005 US\$: (Log-GCF): represents the outlays on additions to the fixed assets of the economy plus the changes in the level of inventories. This variable is often used to measure the growth of the economy along with the Gross Domestic Product. We used the the log form of this indicator and expected this indicator to be positively and significantly associated with good legal environment indicators. We use the log transformation of GCF to make the SD independent of the mean for the variables that are dollar amounts.

(2) Gross Capital formation as \% of GDP (GCF as \% of GDP) GCF is defined above but is scaled by dividing it by the GDP of the country.

(3) Gross Fixed Capital Formation \% of GDP (GFCF/GDP) is the gross domestic fixed investment that includes land improvements plant, machinery and equipment purchases.

(4) GDP-AG is the GDP annual growth in Pct meant to measure the annual economic growth and wealth accumulation. Our hypothesis is that high economic growth countries are not necessarily those that protect their investors better.

(5) Gross value added at factor cost constant 2005 (GVAFC) is the value of output less the value of intermediate consumption.

(6) Manufacturing Value added as \% of GDP (MVA-Asin) measuring the extent of wealth creation from the manufacturing sector. We used the Asin transformation to make the data normally distributed.

\subsection{Methodology}

The hypothesis to test in this study is that the legal environment in which businesses operate matters for the liquidity and depth of the stock market, the availability of credit in the banking sector and economic activity and growth.

To unravel the relationship between access to credit and shareholders' legal rights protection, we use a $T$-test of the significance of the difference between the means of the financial indicators of different countries with different levels of investor protection. Because the number of indicators that we are dealing with is relatively high (20 indicators of investor's rights protection and 14 indicators of financial development), and that the dataset is an unbalanced time series, we start by grouping the countries based on their level of investor protection indicators. First, for every country, we compute the average over all years of every rights protection indicator. Second, for every indicator, we rank the countries based on the calculated indicator average. We then divide the countries into three groups of high investor protection, low investor protection and medium investor protection indicator. This procedure is known as Bartlett's three-group method (see Bartlett (1949)) that focuses only on the comparison of the financial indicators between the high investor indicator group and the low investor indicator group of countries. This grouping was repeated 20 times as we have 20 investor protection indicators. The next step is to test if there is a significant difference between the means of the financial indicators of the low investor protection group and the high investor protection group. To do this, we use a hypothesis testing as follows:

Let $\bar{X}_{h}$ represent the population mean of one financial indicator of the high investor legal protection group and $\bar{X}_{l}$ represent the population mean of a financial indicator of the low investor legal protection group.

$$
\text { HO. } \bar{X}_{h}=\bar{X}_{l} \text { or H0: } \bar{X}_{h}-\bar{X}_{l}=0 \text {. }
$$


Ha. $\bar{X}_{h}>\bar{X}_{l}$ or: Ha $: \bar{X}_{h}-\bar{X}_{l}>0$.

We use a $T$-test for two population means with two unknown population variances and calculated the following statistic:

$$
t=\frac{\bar{X}_{h}-\bar{X}_{l}}{\sqrt{\frac{S_{h}^{2}}{n_{h}}+\frac{S_{l}^{2}}{n_{l}}}}
$$

Agency costs and credit availability

where:

(1) $S_{h}^{2}$ is the variance of the financial indicator of the high investor protection group.

(2) $S_{l}^{2}$ is the variance of the financial indicator of the high investor protection group.

(3) $n_{h}$ and $n_{l}$ are the group sizes (number of observation years times countries).

The $T$-test was repeated 280 times (14 financial and economic indicators x 20 legal protection indicators).

If there is no association between the financial development indicator and investor protection variables, then the average value of the financial development indicator should not differ among the groups characterized as having low or high investor protection indicator and $\bar{X}_{h}-\bar{X}_{l}=0$ cannot be rejected, and the value of the $T$ statistic should be statistically insignificant.

We used the $p$-values to decide whether the $t$ value is significant or not because the degree of freedom differs for different indicators due to the unbalanced dataset. However, we chose to report the $t$ values as they display the sign of the association, which is useful information. The $p$-values are also provided in the summary table in Table A1.

For example, we consider the relationship between the variable Protecting Minority Investors distance to frontier index (PMI DTF) in Table 1, and the variable measuring the extent of the banking sector to finance the private sector DCB. Table 1 shows that the $T$-test gives a value of 6.17 for this association which is positive and significant at the 0.001 probability level. The degrees of freedom represent the number of observations (number of countries times the number years for which we have an indicator) minus 2.

\subsection{Results}

We organize our results in three sections first, we focus on the PMI indicators; second, we focus on the aspect of enforcing contracts and last, we discuss the relevance of bankruptcy laws.

3.3.1 Does investors' rights protection matter? In Table 1, we report the results of the association between the PMI indicators and (1) the credit available via the banking sector (DCPS, DCB and DCP), and (2) the extent of the stock market to finance the corporate sector (STT, STTV, Log-MC and MC) and (3) some economic growth variables (Log-GCF, GCF, GFCF, GDP-AG, GVAFC and MVA). The *** indicates a significance level of more than 99.9 $\%$ which means that the probability that the means of the two groups are equal is less than $0.1 \%$. The ** indicate a significance level of more than $99 \%$ and $\mathrm{a} *$ indicates a significance level of more than $95 \%$.

Access to Credit: Our results suggest clearly a positive and highly significant relationship between variables that measure the availability of domestic credit to the private sector, by financial corporations (banks, nonbanks, trade finance and other financial nonequity corporations) (DCPS) and by Banks (DCB) and by all financial institutions (DCP) to finance the private sector and the indicators that measure the extent of investors' rights protections as measured by all the PMI indicators. Also, we note a positive and significant 


\section{EJMBE 31,3}

296

Table 1.

Minority investors' rights, banking sector, stock market and economic indicators

\begin{tabular}{|c|c|c|c|c|c|c|c|c|}
\hline & PMI_DTF & PMI_SMIP & PMI_SIP & PMI_ESS & PMI_EDLI & PMI_ED & PMI_ECIR & PMI_ESG \\
\hline \multicolumn{9}{|c|}{ Availability of financing via the Banking Sector } \\
\hline DCPS & $6.42^{* * * *}$ & $4.45^{* * * *}$ & $6.63 * * *$ & $3.85 * * * *$ & $4.84^{* * * *}$ & $2.90 * *$ & $4.45^{* * * *}$ & $4.39 * * *$ \\
\hline DCB & $6.17 * * *$ & $4.19 * * *$ & $6.32 * * *$ & $3.57^{* * * *}$ & $4.73^{* * * *}$ & $2.75^{* * *}$ & $4.28 * * *$ & $4.39 * * *$ \\
\hline DCP & $5.71 * * *$ & $4.64 * * *$ & $5.81 * * *$ & $3.37 * * *$ & $4.69 * * *$ & $2.34 *$ & $3.55^{* * * *}$ & $4.34 * * *$ \\
\hline GDS & $2.39^{*}$ & 1.31 & $2.34^{*}$ & -0.88 & $2.55^{*}$ & $2.84 * *$ & 0.77 & 1.07 \\
\hline \multicolumn{9}{|c|}{ Availability of financing and firm valuation via stock market } \\
\hline STT & $2.00^{*}$ & 0.18 & 1.57 & -0.78 & -0.20 & $2.46^{* *}$ & -0.18 & -0.08 \\
\hline Log MC & $3.39 * * *$ & $2.29 *$ & $3.23 * *$ & -0.12 & 1.70 & $6.08 * * *$ & 1.52 & 1.58 \\
\hline $\mathrm{MC} / \mathrm{GDP}$ & $2.25^{*}$ & 1.66 & $2.10^{*}$ & 1.01 & $3.48 * * *$ & 1.88 & 1.61 & -0.02 \\
\hline STTV & $2.10^{*}$ & 1.11 & 1.66 & 0.44 & $1.83^{*}$ & $2.04^{*}$ & 1.27 & -0.61 \\
\hline \multicolumn{9}{|c|}{ Capital accumulation and investment } \\
\hline Log GCF & $6.08^{* * * *}$ & $4.15^{* * * *}$ & $5.84 * * *$ & 1.90 & $3.48^{* *}$ & $3.53^{* *}$ & $3.55^{* *}$ & $5.26 * * *$ \\
\hline GDP-AG & $2.02 *$ & 1.25 & $2.42^{*}$ & 1.13 & 1.58 & -0.99 & 1.39 & 1.21 \\
\hline GCF/GDP & 1.16 & -1.56 & 0.85 & -1.82 & 0.47 & 1.93 & -0.84 & -1.54 \\
\hline $\mathrm{GFCF} / \mathrm{GDP}$ & 0.99 & $-2.15^{*}$ & 0.57 & $-2.55^{*}$ & 0.44 & 1.39 & -1.29 & $-2.08^{*}$ \\
\hline Log & $2.94^{* * *}$ & $5.92^{* * * *}$ & $2.61^{* *}$ & 0.64 & 1.46 & $4.12 * * *$ & $2.02^{*}$ & $6.85^{* * *}$ \\
\hline $\begin{array}{l}\text { GVAFC } \\
\text { asin_MVA }\end{array}$ & 1.04 & $2.19^{*}$ & 0.80 & 0.44 & 0.60 & -0.21 & 0.46 & $3.53 * * *$ \\
\hline
\end{tabular}

Note(s): The **** indicates a significance level higher than $99.9 \%$, which means that the probability that the two groups' means are equal is less than $0.1 \%$. The ** indicate a significance level higher than $99 \%$, and a * indicates a significance level higher than $95 \%$. Refer to Section 3.1 for variables definitions

relationship between the extent of banks to finance the private sector and the extent of investor protection indicators. This is strong evidence that investors' protection matters for the banking sector to fulfill its role of financing the corporate sector.

Valuation of traded companies and access to financing via the stock market: The extent of the stock market to finance the economy as measured by the variables Stocks traded Turnover ratio (STT) and the value of stocks traded as \% of GDP (STTV), as well as by market capitalization as a \% of GDP (MC) and Log of Market capitalization is also significantly related to the legal rights protection indicators. All these variables show a positive and significant association with the PMI DTF, the Extent of disclosure index (PMI_ED) and the extent of the director liability index (PMI-EDLI). The strength of investor protection and extent of minority shareholders protection indexes are also associated with higher market capitalization and hence with a better valuation of listed companies. Therefore, we can already conclude that two variables related to the regulation in terms of disclosure requirement and director liability, in cases of litigation between shareholders and directors, do matter for the liquidity of the stock market and for availability and valuation of equity capital for firm financing. Our results represent evidence of a strong positive association between the extent of investors' protection and firm access to finance.

Investment and Value added by the corporate sector: The results are less obvious for the economic growth indicators. Only Gross capital formation (GFCF) and Gross value added (GVAFC) that measures the addition of fixed assets (capital investment) and wealth accumulation from the manufacturing sector are positively and strongly associated with indicators of protecting investors' rights as measured by the PMI indexes. In fact, GDP growth does not seem to be higher for countries that protect their investors better. This result is expected as many high-growth wealthy countries do not provide legal protection to outside investors and minority shareholders or creditors. This result supports findings by Roe and Siegel (2013) suggesting that for financial development to be translated into economic 
growth, other factors like political stability matter to create an ecosystem conducive to value creation and economic equality.

The legal environment matters for the banking sector to be efficient and for the stock market to be creating value for investors, but our evidence suggests that high economic growth countries are not necessarily those who protect their investors the best.

3.3.2 Does the quality of the judicial system matter?. Access to Credit via the Banking and non-Banking Sector: Table 2 presents the results of the test of the relationship between the quality of the judicial system measured by the enforcing contracts indicators and the extent of the banking sector and other financial institutions to finance the private sector, as well as the Gross Domestic savings. Our results show that all indicators of the availability of credit to the private sector are significantly associated with better enforcing contracts indexes. All variables measuring the time in days it takes to enforce a contract EC-TD cost as $\%$ of claim EC - C and as \% of estate EC-CE, and the number of procedures involved to enforce contract EC-P are all negative and significant (the lower, the better). They have not only the right sign as the association is negative as expected but they also are highly significant. This result means that the longer the time of contract enforcement, the lower the availability of credit to finance the business environment.

Valuation of traded companies and access to financing via the stock market: As expected, our results show a negative and significant relationship between the stock market development indicators and the enforcing contracts indicators. Moreover, the Distance to frontier index Enforcing Contracts DTF index is positively and significantly linked to financial development indicators that measure the availability of credit to finance the private sector, as well as the stock market liquidity and valuation of listed companies. All other indexes measuring the cost and time of enforcing the contract in an economy have, as expected, a negative association with stock market liquidity and the valuation of companies listed.

Investment and Value added by the corporate sector: Table 2 also highlights that all enforcing contract indicators are linked to better investment (as measured by the variable

\begin{tabular}{|c|c|c|c|c|}
\hline & EC_DTF & EC_TD & EC_C & EC_P \\
\hline \multicolumn{5}{|c|}{ Availability of financing via the Banking Sector } \\
\hline DCPS & $6.11 * * *$ & $-3.91 * * *$ & $-4.26^{* * * *}$ & $-4.81^{* * *}$ \\
\hline $\mathrm{DCB}$ & $5.93 * * *$ & $-3.55^{* * *}$ & $-4.52^{* * * *}$ & $-4.42^{* * * *}$ \\
\hline DCP & $6.52^{* * * *}$ & $-4.10^{* * * *}$ & $-4.75^{* * * *}$ & $-4.44^{* * * *}$ \\
\hline GDS & $4.65^{* * * *}$ & $-2.62^{* *}$ & $-4.85^{* * * *}$ & $-2.21^{*}$ \\
\hline \multicolumn{5}{|c|}{ Availability of financing and firm valuation via Stock market } \\
\hline STT & $3.80 * * *$ & $-2.95 * *$ & $-2.57^{*}$ & $-2.59 *$ \\
\hline Log-MC & $5.06^{* * *}$ & $-2.33^{* *}$ & $-2.86^{* * *}$ & $-6.16^{* * * *}$ \\
\hline $\mathrm{MC} / \mathrm{GDP}$ & $3.68 * * *$ & -1.54 & 0.42 & $-5.30 * * *$ \\
\hline STTV & $4.60 * *$ & $-3.42^{* *}$ & -1.24 & $-5.06^{* * *}$ \\
\hline \multicolumn{5}{|c|}{ Capital accumulation and investment } \\
\hline log_GCF & $7.62 * * *$ & $-2.65^{* *}$ & $-7.94^{* * * *}$ & $-6.55^{* * *}$ \\
\hline GDP-AG & $3.56^{* * *}$ & $-3.13^{* *}$ & -1.23 & -1.84 \\
\hline GCF/GDP & $3.48^{* * * *}$ & $-3.30 * * *$ & -1.67 & -1.60 \\
\hline GFCF/GDP & $4.44^{* * *}$ & $-4.05^{* * * *}$ & $-2.08^{*}$ & -0.81 \\
\hline Log_GVAFC & $7.76^{* * * *}$ & $-3.67 * * *$ & $-7.49^{* * * *}$ & $-6.73^{* * *}$ \\
\hline asin_MVA & $4.53 * * *$ & -0.70 & $-3.50^{* * * *}$ & $-4.89 * * *$ \\
\hline
\end{tabular}

Note(s): The *** indicates a significance level of more than $99.9 \%$, which means that the probability that the means of the two groups are equal is less than $0.1 \%$. The ** indicate a significance level of more than $99 \%$, and a * indicates a significance level of more than $95 \%$. Refer to Section 3.1 for variables definitions
Agency costs and credit availability 
EJMBE 31,3

\section{8}

$\mathrm{GCF}$ ), and to a higher value, added by the manufacturing sector, as measured by both GVAF and MVA. This is a very interesting result as it provides strong evidence that efficient contract enforcement is crucial to the enhancement of corporate investment in fixed capital and the value creation by the manufacturing sector to the economy.

Overall, our results represent a strong evidence that the quality of the judicial system that ensures the fairness and efficiency of judicial courts and the rule of law is a strong and positive determinant of firm's access to credit via bank and nonbank financial system and via the stock market, as well as with firm investment through capital accumulation. This result corroborates the finding by Safavian and Sharma (2007), who conclude that "while strengthening creditors rights, increases credit to firms, the payoffs from reforming these rights is lower in countries where the enforcement system functions poorly."

3.3.3 Does protecting creditors' rights during insolvency matter for financing the corporate sector? When corporations and businesses are in a situation of insolvency and financial distress, are creditor's rights protected? This is an important information for the availability of credit finance to the business sector. The efficiency of the insolvency framework will safeguard a high creditor's recovery rate of their capital in the event of financial distress and insolvency.

Access to Credit: The third level of protection is related to resolving disputes that arise in a situation of insolvency. Table 3 reports the results of the test of the association between resolving insolvency indicators and the availability of credit via the banking sector and the stock market activity. The results show a significant association between the availability of credit via bank and nonbank financial institutions for firm financing in the private sector. All indicators show a strong and positive link at least at the $1 \%$ significance level with the resolving insolvency indicators. This is particularly important as it confirms that the existence of bankruptcy law and a good and efficient bankruptcy administration is associated with better access to credit. When Creditors are ensured of the recovery of their capital in a situation of insolvency, they are more inclined to lend and finance the corporate

\begin{tabular}{|c|c|c|c|c|c|}
\hline & RI_DTF & RI_SI & RI_RR & TRI & RI_CE \\
\hline \multicolumn{6}{|c|}{ Availability of financing via the Banking Sector } \\
\hline DCPS & $5.25 * * *$ & $2.63 * *$ & $5.25^{* *}$ & $-2.23^{*}$ & $-3.86 * * *$ \\
\hline DCB & $5.37 * * *$ & $2.45^{* *}$ & $5.37 * *$ & $-2.09 *$ & $-4.16^{* * * *}$ \\
\hline $\mathrm{DCP}$ & $4.50^{* * * *}$ & $2.64 * *$ & $4.50 * *$ & -1.62 & $-3.46^{* * * *}$ \\
\hline GDS & $5.11 * * *$ & $2.42^{* *}$ & $5.11^{* *}$ & $-2.01^{*}$ & $-2.78^{* *}$ \\
\hline \multicolumn{6}{|c|}{ Availability of financing and firm valuation via Stock market } \\
\hline STT & $3.56^{* * * *}$ & $2.24^{*}$ & $3.56^{* *}$ & -0.98 & -1.84 \\
\hline $\log \mathrm{MC}$ & $5.38 * * *$ & $3.39 * *$ & $5.38 * *$ & -0.53 & $-4.35 * *$ \\
\hline $\mathrm{MC}$ & $4.22^{* * * *}$ & 1.22 & $4.22 * *$ & $-2.36^{*}$ & $-2.55^{* *}$ \\
\hline STTV & $5.48^{* * * *}$ & $2.44^{*}$ & $5.48^{* *}$ & -1.74 & $-4.58^{* *}$ \\
\hline \multicolumn{6}{|c|}{ Capital accumulation and firm investment } \\
\hline log_GCF & $8.51^{* * * *}$ & $5.10^{* * *}$ & $8.51 * *$ & $-2.74 * *$ & $-5.40 * *$ \\
\hline GDP_AG & $2.87^{* *}$ & 1.13 & $2.87 * *$ & 0.01 & -1.37 \\
\hline GCF/GDP & 0.98 & -1.79 & 1.08 & -0.49 & -1.08 \\
\hline GFCF/GDP & 0.58 & -1.58 & 0.58 & 0.60 & -1.05 \\
\hline log_GVAF & $7.77^{* * * *}$ & $6.10^{* * *}$ & $7.77 * * *$ & $-2.07^{*}$ & $-5.24 * *$ \\
\hline asin_MVA & $3.65^{* * * *}$ & 3.90 *** & $3.65^{* *}$ & -1.63 & $-2.08 * *$ \\
\hline
\end{tabular}

Efficiency of resolving insolvency framework, banking sector $\mathrm{k}$

Note(s): The *** indicates a significance level of more than $99.9 \%$ which means that the probability that the development and stock market activity means of the two groups are equal is less than $0.1 \%$. The ** indicate a significance level of more th
$\mathrm{a} *$ indicates a significance level of more than $95 \%$. Refer to section 3.1 for variables definitions 
sector. Gross Domestic savings is also significantly associated with all resolving insolvency framework indicators and has the correct sign. An efficient bankruptcy system brings trust and transparency into the process of firm financing via debt. It signals less potential for expropriation of creditors in the event of insolvency, who would more likely agree to finance the firm. Financial transactions would be impossible if creditors were not assured of getting their money back. Our results give support to Gine and Love (2010) studied the reforms in bankruptcy laws in Colombia and provided evidence that firms who are potentially viable are better off being reorganized and benefited from a speedy recovery which ultimately was beneficial to creditors.

Valuation of traded companies and access to financing via the stock market: Our results also confirm that the liquidity of the stock market (STTV, STT) and valuation of listed firms (log of $\mathrm{MC}$ ) are significantly linked to the indicators that measure the extent of resolving insolvency issues. Also, the association is negative when it comes to indicators that measure the time and procedures to resolve insolvency issues, as the lower these indicators are, the better the resolving insolvency framework.

If a bankruptcy regime can separate those firms that should be saved by allowing reorganization from unviable firms that should be liquidated and money returned to creditors, it will translate into a better valuation of viable firms and better opportunities for growth. Our result represents evidence that the valuation of listed firms, stock market liquidity and depth in a country are shaped by the quality of the insolvency framework. Countries should engage in continuously reforming their bankruptcy system as it positively impacts access to credit and creates better opportunities for growth.

More than ever before, bankruptcy laws are needed as the current pandemic is fragilizing millions of businesses around the world whose fate depends on the efficiency of the insolvency framework.

Investment and Value added by the corporate sector: An interesting result is that there does not seem to be any significant relation between resolving insolvency issues and GDP growth rates. Only variables measuring firm capital investment and the total wealth created by the manufacturing sector (GCF), (GVAFC) and MVA, seem to be impacted by the Resolving Insolvency measures put in place in a country. This represents another evidence that the bankruptcy framework matters for the business sector to fulfill its goal of economic wealth and value creation via better financing opportunities, higher job creation and growth prospects.

Last, when lenders cannot access information about potential borrowers, they will be reluctant to lend to entrepreneurs with daring and innovative ideas, which hampers growth. The banking sector development relies on the availability of timely, relevant, and credible information about customers for it to allocate credit efficiently and finance the corporate sector. For this purpose, we also test the significance of the association between DCI (Depth of Credit Information) and the banking sector activity. We expect the variable DCI to be significantly associated with the access to credit via the banking sector. Our results in Table 4 confirm that the depth of credit information (DCI) is a determinant of all measures of availability of credit to the private sector through banks and nonbank financial institutions.

As expected, DCI is not significantly associated with the valuation of firms or with the functioning of the stock market as none of the stock market activity indicators is significant at the $5 \%$ level. However, we document a significant link between the indicator DCI and all measures of value added by the manufacturing sector and investment of the corporate sector (GFCF, GFC and MVA). This is another evidence that the depth of credit information positively impacts value creation and productivity as it facilitates access to financing.

The other indicator tested is LGRI (Strength of Legal rights Index) which is a measure of the degree to which collateral and bankruptcy laws protect the rights of borrowers and lenders. We expect the LGLR indicator to be significantly associated with the banking sector
Agency costs and credit availability 


\begin{tabular}{|c|c|c|c|c|}
\hline \multirow{3}{*}{$\begin{array}{l}\text { EJMBE } \\
31,3\end{array}$} & & \multirow[b]{2}{*}{ ALL_DTF } & \multirow[b]{2}{*}{ DCI } & \multirow[b]{2}{*}{ LGLR } \\
\hline & & & & \\
\hline & Availability o. & aking Sector & & \\
\hline \multirow[b]{5}{*}{300} & DCPS & $6.16^{* * *}$ & $3.61^{* *}$ & 1.22 \\
\hline & $\mathrm{DCB}$ & $6.18^{* *}$ & $3.98 * *$ & 1.34 \\
\hline & DCP & $5.37 * *$ & 3.71 ** & 0.53 \\
\hline & GDS & $3.81^{* *}$ & $2.38^{* *}$ & -1.47 \\
\hline & \multicolumn{4}{|c|}{ Availability of financing and firm valuation via Stock market } \\
\hline \multirow{12}{*}{$\begin{array}{l}\text { Table } 4 \text {. } \\
\text { Efficiency of legal } \\
\text { environment, } \\
\text { availability of credit } \\
\text { and growth }\end{array}$} & log_MC & $3.75^{* *}$ & 0.07 & 0.85 \\
\hline & $\mathrm{MC} / \mathrm{GDP}$ & $3.51^{* *}$ & 0.77 & 1.59 \\
\hline & STTV & $2.64 * *$ & -0.15 & $2.44^{* *}$ \\
\hline & STT & 1.22 & -0.51 & 1.48 \\
\hline & Capital accu & & & \\
\hline & log_GCF & $5.42 * *$ & $2.44^{* *}$ & -0.91 \\
\hline & GDP_AG & 0.58 & 0.48 & 1.81 \\
\hline & GCF/GDP & -1.48 & $-2.58^{* * *}$ & -0.25 \\
\hline & GFCF/GDP & -1.16 & $-2.54 * *$ & 0.03 \\
\hline & log_GVAF & $4.87 * *$ & $5.73 * *$ & -1.33 \\
\hline & asin_MVA & $3.77 * *$ & $6.54 * *$ & -1.72 \\
\hline & \multicolumn{4}{|c|}{$\begin{array}{l}\text { Note(s): The *** indicates a significance level higher than } 99.9 \% \text {, indicating that the probability that the } \\
\text { means of the two groups are equal is less than } 0.1 \% \text {. The ** indicate a significance level higher than } 99 \% \text {, and a } \\
* \text { indicates a significance level higher than } 95 \% \text {. Refer to Section } 3.1 \text { for variables definitions }\end{array}$} \\
\hline
\end{tabular}

and stock market development. Our results in Table 4 indicate that this variable is significantly associates with the total value of stocks traded STTV. Corporations have a better valuation in countries with stronger legal rights indexes.

Finally, the All_DTF variable is an aggregation of the distance to frontier in protecting investors index, enforcing contract index and resolving Insolvency index and is found to be significant at the $1 \%$ level and positively associated with the availability of credit financing, valuation of listed companies and stock market turnover, as well as manufacturing value added and gross capital formation. This result adds support to our findings in the previous sections.

\section{Conclusion}

This paper builds on the recent progress in the corporate governance literature according to which the lack of regulation or the ineffective enforcement, translates into shareholders' and creditors' oppression and can lead to investor expropriation. Agency theory and asymmetry of information explain why in the absence of legal protection of outside investors, financial markets fail to fulfill their role of financing the economy. For instance, if capital providers are not protected from expropriation by controlling shareholders or by opportunistic managers, losses will be incurred for the corporation and more for noncontrolling shareholders. An effective legal protection of outside investors against managerial opportunism requires, first, the legislation and second, the mechanism of enforcing the legislation. Only in this case can the legislation act as a deterrent from diverting shareholders' wealth and undertaking actions that are harmful to outside investors. The third level of protection is needed to resolve disputes that arise in the event of financial distress and insolvency. This third level is particularly important for creditors who risk not recovering their capital in the likely event of bankruptcy. An effective bankruptcy process has an important implication on credit availability but also on effectively supporting distressed firms to reorganize and get back on their feet if they can be viable and unviable firms to be liquidated in a timely manner and 
funds returned to creditors. The current pandemic has pushed many SMEs into distress and hence offers a unique opportunity for countries around the world to implement or reform their bankruptcy laws.

We use in total 20 investor protection, enforcing contracts, and resolving insolvency indicators from the doing business dataset and 14 different indicators of the ease of access to credit, the functioning of the stock market and investment and growth to test our hypothesis that countries that protect better investors and minority shareholders have more developed and efficient financial systems. Our results suggest that the extent of investor protection, enforcing contracts and resolving insolvency are significantly associated with the role played by banks and nonbanks, as well as the stock market in financing the corporate sector in 189 different countries during 2003-2017. The aspects of rights protection tested here can be considered as the conditions under which creditors and minority investors can find a safe investment avenue for their capital. Without them, credit allocation is not optimal, equity finance is not easily raised, and investment and growth are hampered. The policy implication from this study indicates that countries ought to develop an investor and creditor-friendly legislation that protects creditors' rights during bankruptcy and ensure fairness and efficiency of the court system as these are important ingredients for a developed financial system.

Finally, the availability of the unique World Bank dataset has made this research project possible, but more would be accomplished in the future when a longer time series of these data becomes available as we will be able to investigate the exact causal relationship between reforms in the legal system, finance, entrepreneurship and growth.

\section{Note}

1. https://datacatalog.worldbank.org/search?search_api_views_fulltext_op=AND\&query=domestic credit to the private sector\&nid $=\&$ sort_by $=$ search_api_relevance\&sort_order $=$ DESC

\section{References}

Antill, S. (2020), "Do the right firms survive bankruptcy?", available at: https://ssrn.com/ abstract=3383227 or http://dx.doi.org/10.2139/ssrn.3383227 (accessed 15 September 2020).

Antill, S. and Grenadier, S.R. (2019), "Optimal capital structure and bankruptcy choice: dynamic bargaining versus liquidation”, Journal of Financial Economics, Vol. 133, pp. 198-224.

Armour, J., Simon, D., Sarkar, P., Siems, M. and Singh, A. (2008), "Shareholder protection and stock market development: an empirical test of the legal origins hypothesis", CBR WP No. 108/, University of Cambridge. doi: 10.1111/j.1740-1461.2009.01146.x.

Armour, J., Hansmann, H. and Kraakman, R. (2009), Agency Problems, Legal Strategies and Enforcement Discussion Paper No. 644 7/, Harvard Law School Cambridge, MA 02138.

Bartlett, M.S. (1949), "Fitting a straight line when both variables are subject to error", Biometrics, Vol. 5, pp. 207-212.

Beck, T., Demirguc-Kunt, A. and Maksimovic, V. (2005), "Financial and legal constraints to growth: does firm size matter?", Journal of Finance, Vol. 60 No. 1, pp. 137-177.

Berdugo, B. and Hadad, S. (2009), "How does investors' legal protection affect productivity and growth?", available at: https://ssrn.com/abstract=1412324 or http://dx.doi.org/10.2139/ssrn. 1412324 .

Bernstein, S., Colonnelli, E., Giroud, X. and Iverson, B. (2019a), "Bankruptcy spillovers", Journal of Financial Economics, Vol. 133, pp. 608-33.

Bernstein, S., Colonnelli, E. and Iverson, B. (2019b), "Asset allocation in bankruptcy", The Journal of Finance, Vol. 74, pp. 5-53. 
EJMBE 31,3

Burkart, M. and Panunzi, F. (2006), "Agency conflicts, ownership concentration, and legal shareholder protection”, Journal of Financial Intermediation, Vol. 15, p. 31.

Burunciuc, C. and Gonenc, H. (2021), "Reforms protecting minority shareholders and firm performance: an international evidence", Journal of Risk and Financial Management, Vol. 14, p. 5, available at: https://www.mdpi.com/1911-8074/14/1/5.

Carlin, W. and Mayer, C. (2003), "Finance, investment, and growth", Journal of Financial Economics, pp. 191-226.

Claessens, S., Djankov, S. and Lang, L. (2000), "The separation of ownership and control in East Asian corporations", Journal of Financial Economics, Vol. 58, pp. 81-112.

Claessens, S., Fan, J.P.H. and Lang (2002), "Corporate governance in Asia", A Survey International Review of Finance, Vol. 3 No. 2, pp. 71-103.

Deakin, S., Sarkar, P. and Siems, M. (2018), "Is there a relationship between shareholder protection and stock market development?", Journal of Law, Finance, and Accounting, Vol. 3 No. 1, pp. 115-146.

Dyck, A. and Zingales, L. (2004), "Private benefits of control: an international comparison", The Journal of Finance, Vol. 59, pp. 537-600.

Farrar, J.H. and Boulle, L. (2001), "Minority shareholder remedies - shifting dispute resolution paradigms", Bond Law Review, Vol. 13 No. 2, pp. 273-304.

Gine, X. and Love, I. (2010), "Do reorganization costs matter for efficiency?", Evidence from a Bankruptcy reform in Colombia Journal of Law and Economics, University of Chicago Press, Vol. 53 No. 4, pp. 833-864.

Gormley, T.A. and Matsa, D.A. (2016), "Playing it safe? Managerial preferences, risk, and agency conflicts", Journal of Financial Economics, December 2016, Vol. 122 No. 3, pp. 431-455.

Jensen, M.C. and Meckling, W.H. (1976), "Theory of the firm: managerial behavior, agency costs and ownership structure", Journal of Financial Economics, Elsevier, Vol. 3 No. 4, pp. 305-360.

Kumar, K., Rajan, R. and Zingales, L. (1999), "What determines firm size NBER”, Working Paper No. 7208, available at: https://www.nber.org/papers/w7208.

La Porta, R., Lopez-De-Silanes, F., Shleifer, A. and Vishny, R. (1997), "Legal determinants of external finance", The Journal of Finance, Vol. 52 No. 3, pp. 1131-1150.

La Porta, R., Lopez-de-Silanes, F., Shleifer, A. and Vishny, R.W. (1998), "Law and finance”, Journal of Political Economy, Vol. 106, pp. 1113-1155.

La Porta, R., Lopez-de-Silanes, F., Shleifer, A. and Vishny, R.W. (2002), "Investor protection and corporate valuation", Journal of Finance, Vol. 57 No. 3, pp. 1147-1170.

LaPorta, R., Lopez-de-Silanes, F., Shleifer, A. and Vishny, R. (2000), "Investor protection and corporate governance", Journal of Financial Economics, Vol. 58 Nos 1-2, pp. 3-27.

Love, I. (2003), "Financial development and financing constraints: international evidence from the structural investment model”, Review of Financial Studies, Vol. 16 No. 3, pp. 765-91.

Neira, J. (2019), "Bankruptcy and cross-country differences in productivity", Journal of Economic Behavior and Organization, Vol. 157, pp. 359-381.

Nenova, T. (1999), "The value of a corporate vote and private benefits: a cross-country analysis, Working Paper, Harvard University Cambridge, MA.

Ponticelli, J. and Alencar, L.S. (2016), "Court enforcement, bank loans, and firm investment: evidence from a bankruptcy reform in Brazil", The Quarterly Journal of Economics, Vol. 131 No. 3, pp. 1365-1413.

Roe, M.J. and Siegel, J.I. (2013), "Political instability: its effects on financial development, its roots in the severity of economic inequality", Journal of Comparative Economics, Vol. 39 No. 2011, pp. 279-309.

Ross, S. (1973), "The economic theory of agency: the principal's problem", American Economic Review, Vol. 63, pp. 134-39. 
Safavian, M. and Sharma, S. (2007), "When do creditors rights work", Journal of Comparative Economics, Vol. 35 No. 3, pp. 484-508.

Shleifer, A. and Wolfenzon, D. (2002), "Investor protection and equity markets", Journal of Financial Economics, Vol. 66, pp. 3-27.

Agency costs and credit availability

Wurgler, J. (2000), "Financial markets and the allocation of capital", Journal of Financial Economics, Vol. 58 Nos 1-2, pp. 187-214.

Zingales, L. (1994), "The value of the voting right: a study of the Milan stock exchange", Review of Financial Studies, Vol. 7, pp. 1 25-148.

\section{Corresponding author}

Mejda Bahlous-Boldi can be contacted at: mbbcada@rit.edu 


\section{EJMBE \\ 31,3}

304

\section{Appendix}

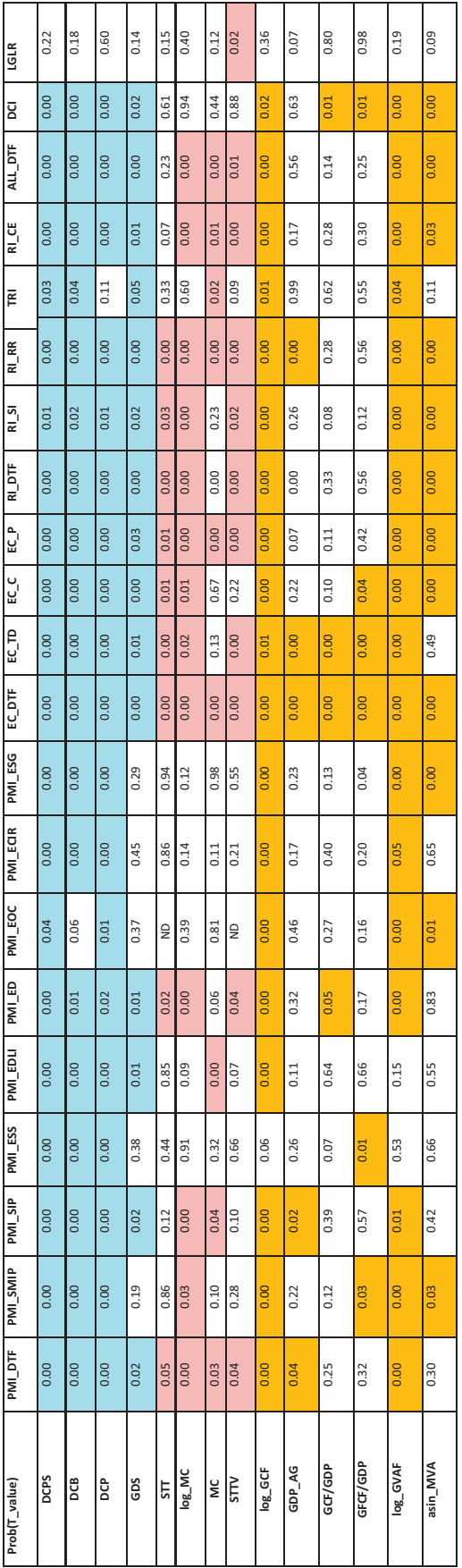

Table A1.

Probability that there is no difference between the means in the groups of countries with high standards of investors protection and those with weak standard of investor rights protection 